
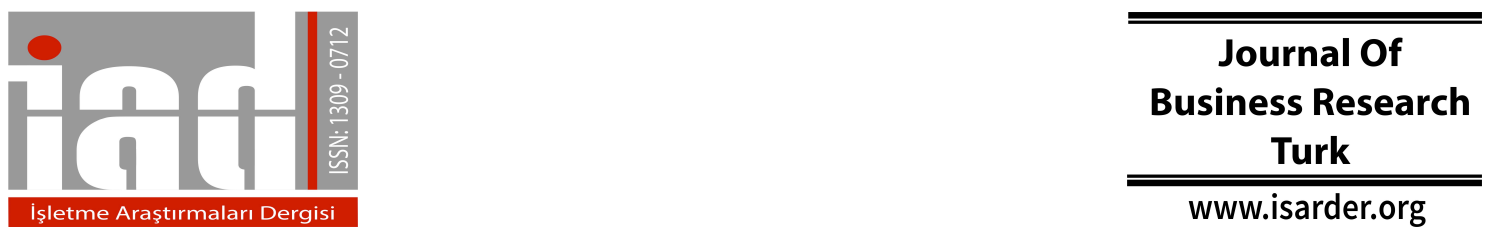

\title{
Exploring the Interaction Between Internal Customer Satisfaction and Talent Waste: A Lean Management Perspective ${ }^{1}$
}

\author{
Yeşim Deniz ÖZKAN ÖZEN \\ Ege University \\ Faculty of Economics and Administrative \\ Sciences \\ Department of Business Administration \\ Izmir, Turkey \\ orcid.org/0000-0003-4520-6590 \\ yesimdenizozkan@gmail.com
}

\author{
Keti VENTURA \\ Ege University \\ Faculty of Economics and Administrative \\ Sciences \\ Department of Business Administration \\ Izmir, Turkey \\ orcid.org/0000-0002-6422-0518 \\ keti.ventura@ege.edu.tr
}

\begin{abstract}
Principles of lean management have become more popular in recent years and the implementation area of Lean, spread from manufacturing environment to service sectors due to its wide applicability. Human centric structure of service sector reveals the need of lean principles which focuses on improvements related to employees. In lean thinking, elimination of wastes is one of the priority and it is essential to eliminate them for organizational enhancements. Wastes in lean were firstly defined under seven categories as overproduction, over-processing, waiting, motion, inventory, defect, transportation for manufacturing environment. However, these wastes were not found adequate, since one of the most important factor in organizations, human, was ignored. Therefore, the $8^{\text {th }}$ waste of lean was presented as "talent" in order to include the human factor and it refers to underutilization of people's talent, knowledge, skills and abilities. As eliminating talent waste has been perceived as an important concept, it should be a significant driver of increasing internal customer satisfaction. This study aims to explore the relation between talent waste and internal customer satisfaction while considering level of top management commitment. Within this context a survey was conducted with the participation of whitecollar internal customers to understand their perception of talent waste related to their jobs. At the end of the study, it is found that talent waste partially mediates the relationship between top management commitment and internal customer satisfaction.
\end{abstract}

Keywords: Internal Customer Satisfaction, Talent Waste, Mediation

\section{Introduction}

Even though it can be traced back till the works of Deming and Taylor, the core of the lean concept is based on Toyota manufacturing systems. "Lean" has evolved to the state of art in manufacturing environment (Dombrowski \& Mielkea, 2013) however, principles of lean are also used commonly in service sectors including finance,

\footnotetext{
* Earlier version of this study was presented in 14th International Logistics and Supply Chain Congress on December
} 1-2, 2016 in İmir. 
healthcare, education, hospitality etc. (Maskell \& Kennedy, 2007; Stanton, et al., 2014; Balzer, Brodke, \& Kizhakethalackal, 2015; Vlachos \& Bogdanovic, 2013). Shah and Wards (2007) defined lean as "an integrated socio-technical system whose main objective is to eliminate waste by concurrently reducing or minimizing supplier, customer, and internal variability." The term "lean" was first used by Jim Womack and his research team to describe the Toyota's business ideology, whose priority was focusing on customer needs while minimizing activities that do not add value to the system, in other words, wastes.

Wastes cause organizations to be less effective. Therefore, elimination of wastes is one of the priorities of lean management practices. Lean is also defined as an organizational performance management system which includes the collaboration of all employees from different stages to identify, minimize or eliminate activities that do not create value for the customers or stakeholders (Kavanagh \& Krings, 2011). According to Hines and Rich (1997), process of elimination or reduction of wastes starts with identifying them on value stream and continues with removing them from stream by using appropriate tools and techniques. In order to eliminate these wastes, five main principles of lean are considered (Hines \& Taylor, 2000; Hines \& Rich, 1997). The first one is specifying value added and non-value added activities from customer perspective. The next one is identifying all the needed stages to design, order and produce the products through the value stream in order to mention non-value adding wastes. Making those actions that create value flow without wastes and creating a pull system according to customer expectations are followed by striving for perfection by continuously removing wastes.

Wastes in Lean Management were firstly defined by Taiichi Ohno, formerly the chief engineer at Toyota, and they are also called as muda (Womack \& Jones, 1996). Taiichi Ohno (1978) classified wastes for manufacturing industry: over-processing, overproduction, waiting, transportation, unnecessary motion, unnecessary inventory and defects. Over-processing, or in other words inappropriate processing, refers to using the wrong set of tools, procedures or systems during the work, while a simpler way would be more effective (Hines \& Taylor, 2000). It occurs when the process is more complex than necessary or the process/ product includes more features than needed (Brenson \& Kulkarni, 2011). Main factors which cause over-processing were stated as poor understanding of the customer's true requirements, the failure to communicate customer requirements to workers, or failure in designing the products according to customer requirements (Kavanagh \& Krings, 2011). Overproduction is one of the most common waste in manufacturing environment. Basically, it refers to producing too much without customer demands. It is usually caused by poor information flow which results in an excess inventory (Hines \& Taylor, 2000). As it can be understood from its name, waiting waste refers to unused time or inactivity period of employees, machines, goods resulting ineffective flows and long lead times (Hicks, 2007). The next waste is transportation waste which is unnecessary or excessive movement of people, materials, goods, information etc. (Hines \& Taylor, 2000) that does not add value to the process. The similar concept is unnecessary motion which contains only employee movements that does not add value (Benson \& Kulkarni, 2011). As it was mentioned before, unnecessary inventory is the cause of overproduction. It refers to excessive storage and delay of information or products. It directly increases the costs therefore; it is important for organizations to eliminate inventory related wastes from working environment 
(Karlsson \& Åhlström. 1996). Finally, defects, or in other words scraps, may be the most common wastes of any kind of organizational environment including manufacturing and service, and refers to damaged goods or non-compliant products (Pereira, 2009).

However, these well-known 7 wastes, explained above, defined and categorized exclusively for the manufacturing environment; were not found sufficient by Womack and Jones, 1996, for more general use; since the human factor is not included and human related wastes are disregarded. Therefore, in 1996, Womack and Jones introduced the $8^{\text {th }}$ waste, "talent", which refers to underutilizing talent, knowledge and skills. Womack and Jones (1996), define talent waste as underutilization of people's talent, knowledge, skills and abilities. Risks of talent waste were stated as frustrated and unfulfilled employees, high turnover rates, poor morale and lack of belief to change. Most of these studies paid attention to the similar research areas and used the term "talent waste" at some points. However, lean perspective has not been used to analyze over-qualification, underutilization, over-education, skill mismatches, in other words, talent waste. This paper intends to explore the relation between talent waste and internal customer satisfaction. Within this context, a survey is conducted with white-collar internal customers to understand their perception of talent waste related to their jobs. In the first part, a literature review is given and in the second part, research methodology and the results are discussed.

\section{Literature Review}

The $8^{\text {th }}$ waste of Lean Management is defined in different ways by different authors (Hicks, 2007; Martin and Arokiam, 2007; Brenson and Kulkarni, 2011; Kavanagh and Krings, 2011), however there are some common terms in all definitions. Brenson and Kulkarni (2011) defined the $8^{\text {th }}$ waste of lean as "under-utilized talent" and explained it as improper utilization of talent and creativity loss. At the same study, it is stressed that if talent waste elimination is achieved, many benefits are gained for the organization. Moreover, Kavanagh and Krings (2011) named the 8th waste as "underutilizing people's abilities" and explained it as the failure to make use of employees' knowledge, skills and abilities. As an example, using highly trained and capable proffessionals rather than using less trained people for performing easy tasks can be a failure. According to Hicks (2007), 8th waste of Lean Management relates to the underutilization of people and in particular, their ideas and creative input for improving the processes and practices. Furthermore, Martin and Arokiam (2007) defined the $8^{\text {th }}$ waste as "skill utilization" and defined it as employee with the right set of skills is missed out performing the appropriate task.

As it can be understood from all definitions above, the $8^{\text {th }}$ waste of Lean Management is related to utilizing peoples' talents, knowledge, skills, background, abilities etc.. Therefore, according to these explanations, it can be said that $8^{\text {th }}$ waste of lean includes the concepts of over-qualification, underutilization of skills, skill mismatches and over-education.

Wasting talent at the working environment is not a new concept in the literature and many authors had researches in different forms so far. More than two decades ago, Alba-Ramirez (1993) focused on over-education, and in that study, over-education is identified through "information obtained from employees about the educational background they actually have and the schooling they report as necessary to perform 
their respective jobs." As a similar concept, skill underutilization was defined as "employment which underuses workers' skills" (Felstad \& Green, 2013). Fine and Nevo (2008) had seen over qualification as a multidimensional term, and referring different kinds of situations of improper employment. These situations were named as overeducation, over-experience, and skill underutilization which is referred to the possession of a greater level of education, experience, or skill that is required for a given job. These explanations are also concurrent with the focus area of this research. Similarly, Christiansen, Fliter and Frost (2014), focused on person-job fit and defined it as match between persons' skills, knowledge, abilities and the demands of the job. The term talent waste was used by Paolo and Mane (2014) in their research focusing on qualification and skill mismatches on $\mathrm{PhD}$ graduates. According to their review, qualification mismatch solely is not strongly related to job satisfaction; however, underutilization of skills has more serious results, especially when convoyed by educational mismatch. Furthermore, Badillo-Amador and Villa (2013) investigated jobworker educational mismatches in Spanish labor market and concluded that job satisfaction is predicted by skill mismatches better than educational mismatches. Badillo-Amador and Villa (2013) also added that employees' present job satisfaction level is influenced by their previous job perceptions. Table 1 provides the short summary of some of the recent studies.

Table 1: Literature Review

\begin{tabular}{|c|c|c|}
\hline Author(s) & Focused Area & Main Findings \\
\hline $\begin{array}{l}\text { Johnson and } \\
\text { Johnson (2000) }\end{array}$ & $\begin{array}{l}\text { Perceived over qualification and } \\
\text { dimensions of job satisfaction }\end{array}$ & $\begin{array}{l}\text { Perceived over qualification has a negative } \\
\text { effect on job satisfaction. However, the } \\
\text { relationships varied by dimension of } \\
\text { perceived over qualification and dimension of } \\
\text { job satisfaction. }\end{array}$ \\
\hline $\begin{array}{l}\text { Allen and } \\
\text { Velden }(2001)\end{array}$ & $\begin{array}{l}\text { Relation between educational } \\
\text { mismatches and skill mismatches }\end{array}$ & $\begin{array}{l}\text { Skill mismatches are much better predictors of } \\
\text { job satisfaction and on-the-job search than } \\
\text { educational mismatches. }\end{array}$ \\
\hline Vieira (2005) & $\begin{array}{l}\text { Relation between skill mismatch } \\
\text { and job satisfaction }\end{array}$ & $\begin{array}{l}\text { Overall job satisfaction is adversely affected } \\
\text { by perceived over-qualification. Same is valid } \\
\text { for satisfaction as well. A worker would be } \\
\text { willing to take a wage cut in order to preclude } \\
\text { over-qualification. }\end{array}$ \\
\hline $\begin{array}{l}\text { Morrison et. Al. } \\
(2007)\end{array}$ & $\begin{array}{l}\text { Linking the key job characteristics } \\
\text { of perceived control and perceived } \\
\text { cognitive demand to perceived skill } \\
\text { utilization and intrinsic job } \\
\text { satisfaction }\end{array}$ & $\begin{array}{l}\text { The relationship between perceived job } \\
\text { demand and perceived skill utilization was } \\
\text { mixed but no mediating e ect was evident. } \\
\text { The level of both perceived demand and } \\
\text { perceived control dictates the nature of the } \\
\text { joint influence of both job characteristics on } \\
\text { perceived skill utilization and work attitudes } \\
\text { such as job satisfaction. }\end{array}$ \\
\hline $\begin{array}{l}\text { Fine and Nevo } \\
(2008)\end{array}$ & $\begin{array}{l}\text { Examining the concept of cognitive } \\
\text { over-qualification }\end{array}$ & $\begin{array}{l}\text { Cognitive over-qualification was found to be } \\
\text { associated with job dissatisfaction, but was } \\
\text { only weakly related to measures of job and } \\
\text { training performance. }\end{array}$ \\
\hline
\end{tabular}




\begin{tabular}{|c|c|c|}
\hline $\begin{array}{l}\text { Fleming and } \\
\text { Kler (2008) }\end{array}$ & $\begin{array}{l}\text { Over education and work place } \\
\text { satisfaction }\end{array}$ & $\begin{array}{l}\text { Although levels of satisfaction remain high, } \\
\text { across all measures of workplace satisfaction, } \\
\text { overeducated workers are less satisfied } \\
\text { compared to their non-over-educated } \\
\text { counterparts. }\end{array}$ \\
\hline $\begin{array}{l}\text { Amador, Nicolas } \\
\text { and Vila (2012) }\end{array}$ & $\begin{array}{l}\text { The consequences on job } \\
\text { satisfaction of job-worker } \\
\text { educational and skill mismatches }\end{array}$ & $\begin{array}{l}\text { Skill mismatches emerge as a much better } \\
\text { predictor of job satisfaction than educational } \\
\text { mismatches as the effects of the latter are } \\
\text { related to unobserved heterogeneity among } \\
\text { workers. } \\
\text { The current level of job satisfaction appears to } \\
\text { be influenced by workers' previous job } \\
\text { perceptions, suggesting a dynamic structure } \\
\text { for job satisfaction. }\end{array}$ \\
\hline $\begin{array}{l}\text { Fleming and } \\
\text { Kler (2014) }\end{array}$ & $\begin{array}{l}\text { Female over education and job } \\
\text { satisfaction }\end{array}$ & $\begin{array}{l}\text { For females with dependent children at home, } \\
\text { over-education has a detrimental effect on a } \\
\text { minority of satisfaction measures, whereas for } \\
\text { females without children at home, over- } \\
\text { education has a detrimental effect on a } \\
\text { majority of satisfaction measures. }\end{array}$ \\
\hline $\begin{array}{l}\text { Paolo and Mane } \\
(2014)\end{array}$ & $\begin{array}{l}\text { Consequences of qualification and } \\
\text { skills mismatch on } \mathrm{PhD} \text { graduates }\end{array}$ & $\begin{array}{l}\text { Graduates who are both overqualified and } \\
\text { overskilled also showed that being } \\
\text { mismatched reduces job satisfaction, } \\
\text { especially for those whose skills are } \\
\text { underutilized. }\end{array}$ \\
\hline $\begin{array}{l}\text { Weymer, Maciel } \\
\text { and Castor } \\
(2014)\end{array}$ & $\begin{array}{l}\text { Influence of over qualification and } \\
\text { individual's learning at work about } \\
\text { their satisfaction }\end{array}$ & $\begin{array}{l}\text { Over qualification and exploration learning } \\
\text { influence the satisfaction indeed, but the } \\
\text { exploitation learning does not influence } \\
\text { satisfaction. }\end{array}$ \\
\hline
\end{tabular}

Job satisfaction is an attitudinal reaction and is related to the feeling of oneself about their jobs and different aspects of the job (Spector, 1997). According to Rafferty and Griffin (2009), there has been a debate in the definition of job satisfaction about its being an emotional reaction and/or cognitive response. However, he stressed that it will continue to progress as insights grow from new methodologies. The literature review in Table 1 shows some important studies related to the investigation of the relationship of talent waste elements and internal customer job satisfaction.

As Berry (1981) identified the employees as internal customers, their level of satisfaction in their jobs and their importance in satisfying external customers have been stressed by many authors (e.g. Ahmed and Rafiq, 2003). Several factors have been found to influence the satisfaction of internal customers such as job content, pay/compensation, working conditions, security, relation with co-workers, relation with supervisor, job enrichment, high involvement work system (Orpen, 1979; Matzler, Fuchs, and Schubert, 2004; Parvin and Kabir, 2011; Harmon, et.al., 2003). One of the most important factors that causes dissatisfaction of employees is talent waste which comprises over-qualification, underutilization of skills, skill mismatches and overeducation (Allen and van der Velden, 2001; Vieira, J. A. C., 2005; Allen, J., \& De Weert, E., 2007; Mavromaras, Sloane and Wei, 2012) of internal customers. Therefore, 
the fit between employee-job becomes an important aspect for the executives to manage the abilities, competencies and skills to achieve an effective organization (Elegbe, 2016). Al-Yahya (2007) stressed that the problem with many organizations may not be the lack of skills and capabilities, but the lack of appropriate management mechanisms and organizational design that support this. In this regard, senior management should realize the importance of talent which has a direct effect on employee's motivation and satisfaction (Bhatti, 2011).

\section{Field Survey}

The present study represents the relationship between talent waste and internal customer satisfaction and investigates the effect of top management commitment with this issue. With this purpose, a survey is conducted with white-collar internal customers to understand their perception of talent waste related to their jobs between June 2016 and October 2016. A population of white collars is expected to make objective evaluations about their job-talent fit and satisfaction levels. The sample consisted of Turkish white collars who are currently employed at different industries in Izmir. Izmir is sampled due to the convenience in collecting data. Both online surveys and face to face were conducted using convenience sampling method. Main limitations while collection data were; unwillingness for participation, finding the survey time consuming, concerns about confidentiality. Due to these limitations, 385 usable questionnaires consisting of 302 online, 83 face to face were collected. In total, the questionnaire included 26 statements about the respondents' perceptions of talent waste, top management commitment and job satisfaction. Moreover, demographic questions were also used to present the profile of participants.

Scales used in the survey that aim to measure the overall evaluations and perceptions of talent waste were adapted from Johnson (2000), Allen (2001), Green and McIntosh (2007) and Weymer and Maciel (2014), job satisfaction scale was adapted from Spector (1985) and top management commitment was adapted from Visverswaren et al. (1998). 5-point Likert scale of ranging from (1)' 'strongly disagree' to 'strongly agree (5) was utilized. The statements were translated to Turkish for Turkish white collar participants. below.

Given the literature above, the proposed model and the hypothesis are shown

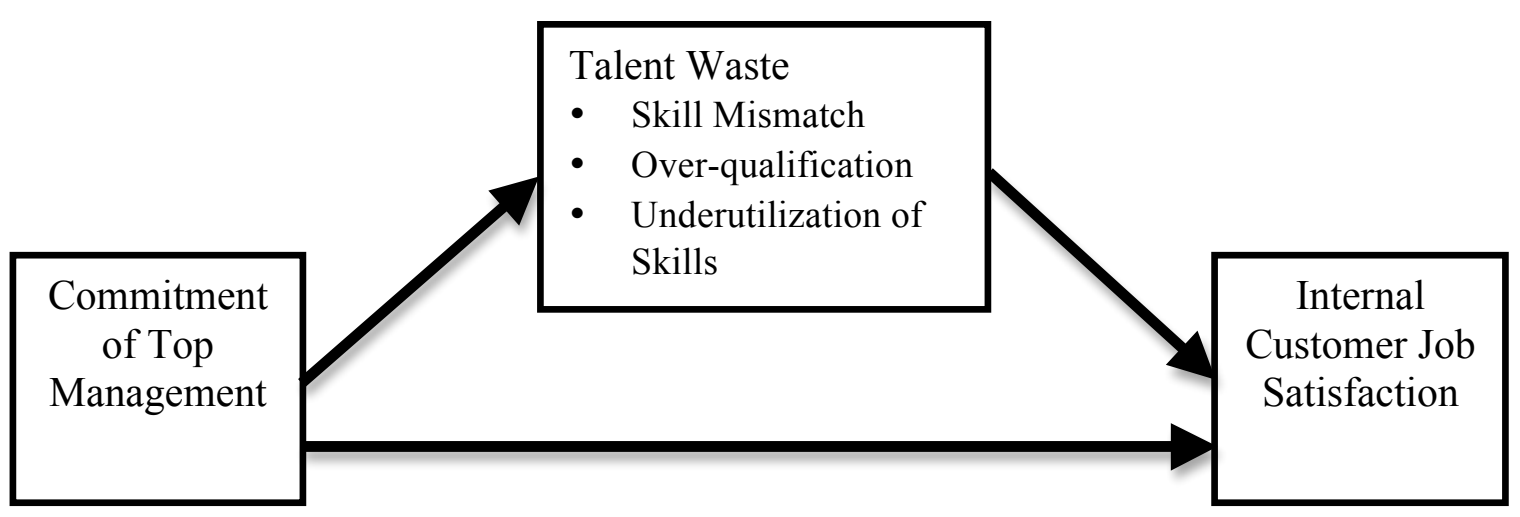

Figure 1: The Conceptual Model 
$\mathrm{H}_{1}$ : The higher level of top management commitment leads to higher level of internal customer satisfaction.

$\mathrm{H}_{2}$ : The higher level of top management commitment leads to lower level of talent waste.

$\mathrm{H}_{3}$ : The lower level of talent waste leads to higher level of internal customer satisfaction.

H4: Talent waste mediates the relationship between top management commitment and internal customer satisfaction.

\section{Data Analysis and Results}

Demographic questions such as gender, age, education, sector, current position and years of experience were asked to respondents and the demographic profiles are shown in Table 2. In order to find out the respondents' general evaluations, one-sample t-test was conducted as appeared in Table 3.

Table 2: Demographic Characteristics of Participants

\begin{tabular}{|c|c|c|c|c|c|}
\hline Gender & $\mathbf{N}$ & $\begin{array}{c}\text { Valid } \\
\text { Percent }\end{array}$ & Current Department & $\mathbf{N}$ & $\begin{array}{c}\text { Valid } \\
\text { Percent }\end{array}$ \\
\hline Male & 239 & 62,1 & Manufacturing & 49 & 13,9 \\
\hline Female & 146 & 37,9 & Marketing/Sales & 80 & 22,7 \\
\hline Total & 385 & 100 & Trade & 7 & 2,0 \\
\hline \multirow[t]{13}{*}{ Missing } & - & & Supply/Purchasing & 23 & 6,5 \\
\hline & & & Accounting/Finance & 30 & 8,5 \\
\hline & & & Human Resources & 19 & 5,4 \\
\hline & & & $\mathrm{R} \& \mathrm{D}$ & 49 & 13,9 \\
\hline & & & IT & 16 & 4,5 \\
\hline & & & Maintenance & 10 & 2,8 \\
\hline & & & Quality & 5 & 1,4 \\
\hline & & & Continuous Improvement & 4 & 1,1 \\
\hline & & & Investment & 6 & 1,7 \\
\hline & & & Management & 17 & 4,8 \\
\hline & & & Others & 37 & 10,5 \\
\hline & & & Total & 352 & \\
\hline & & & Missing & 33 & \\
\hline \multicolumn{3}{|l|}{ Age } & \multicolumn{3}{|l|}{ Current Position } \\
\hline $18-24$ & 29 & 8,2 & Manager & 41 & 11,6 \\
\hline $25-34$ & 198 & 56,3 & Coordinator & 11 & 3,1 \\
\hline $35-44$ & 81 & 23 & Chef & 63 & 17,9 \\
\hline $45-54$ & 40 & 11,4 & Specialist & 171 & 48,6 \\
\hline $55-64$ & 3 & 0,9 & Responsible & 39 & 11,1 \\
\hline $65+$ & 1 & 0,3 & Others & 27 & 7,7 \\
\hline Total & 352 & 100 & Total & 352 & \\
\hline Missing & 33 & & Missing & 33 & \\
\hline \multicolumn{3}{|l|}{ Education } & \multicolumn{3}{|l|}{ Total Years of Experience } \\
\hline Pre-High School & 1 & 0,3 & $<1$ & 29 & 8,2 \\
\hline High-School & 14 & 4,0 & $1-2$ & 47 & 13,4 \\
\hline Undergraduate & 215 & 61,1 & $3-5$ & 17 & 4,8 \\
\hline Postgraduate & 110 & 31,3 & $6-10$ & 58 & 16,5 \\
\hline $\mathrm{PhD}$ & 12 & 3,4 & $11-15$ & 119 & 33,8 \\
\hline Total & 352 & & $16-20$ & 36 & 10,2 \\
\hline \multirow[t]{3}{*}{ Missing } & 33 & & $>20$ & 46 & 13,1 \\
\hline & & & Total & 352 & \\
\hline & & & Missing & 33 & \\
\hline
\end{tabular}




\begin{tabular}{|c|c|c|c|c|c|}
\hline \multicolumn{3}{|l|}{ Sector } & \multicolumn{3}{|c|}{ Total Years in Current Job } \\
\hline Automotive & 30 & 8,5 & $<1$ & 89 & 25,3 \\
\hline Textile & 27 & 7,7 & $1-2$ & 68 & 19,3 \\
\hline Food & 16 & 4,5 & $3-5$ & 21 & 6,0 \\
\hline Electronic & 17 & 4,8 & $6-10$ & 36 & 10,2 \\
\hline Energy & 5 & 1,4 & $>10$ & 138 & 39,2 \\
\hline Construction & 117 & 33,2 & Total & 352 & \\
\hline Logistics & 11 & 3,1 & Missing & 33 & \\
\hline Agriculture & 7 & 2,0 & & & \\
\hline Finance & 18 & 5,1 & & & \\
\hline Service & 14 & 4,0 & & & \\
\hline Education & 9 & 2,6 & & & \\
\hline Advertising & 4 & 1,1 & & & \\
\hline Iron-Steel & 8 & 2,3 & & & \\
\hline Healthcare & 10 & 2,8 & & & \\
\hline Trade & 3 & 0,9 & & & \\
\hline Information Technologies & 10 & 2,8 & & & \\
\hline Defense & 3 & 0,9 & & & \\
\hline Manufacturing & 7 & 2,00 & & & \\
\hline Others & 36 & 10,2 & & & \\
\hline Total & 352 & & & & \\
\hline Missing & 33 & & & & \\
\hline
\end{tabular}

Test value was assigned as 3 , which refers to neither agree nor disagree in one sample t-test. Insignificant statements according to one sample t test were eliminated. Perception of talent waste in terms of educational background and job match is found above average. Participants think that their job allows them to apply their education and work experience. Moreover, they believe that they can easily handle more difficult work and they pose more skills than necessary to do their job. Participants also think that their superiors take care of their opinions. However, results show that participants have doubts about their organization's support designing the job interesting and more rewarding. As it can be seen, in general, level of internal customer satisfaction was found at moderate level

Table 3: Statistics About Participants.

\begin{tabular}{|c|c|c|c|c|c|c|}
\hline Statements* & Mean & $\begin{array}{l}\text { Std. } \\
\text { Dev. }\end{array}$ & $\mathbf{t}$ & df & Sig. & $\begin{array}{r}\text { Cronbach } \\
\text { Alpha }\end{array}$ \\
\hline \multicolumn{7}{|l|}{ Talent Waste } \\
\hline $\begin{array}{l}\text { My current job offers me sufficient scope to use my } \\
\text { knowledge }\end{array}$ & 3,39 & 1,099 & 7,003 & 384 & 0,000 & \multirow{8}{*}{0,730} \\
\hline $\begin{array}{l}\text { My current job offers me sufficient scope to use my } \\
\text { skills. }\end{array}$ & 3,28 & 1,113 & 4,902 & 384 & 0,000 & \\
\hline My educational background and my current job fits & 3,36 & 1,159 & 6,022 & 384 & 0,000 & \\
\hline My skills and my current job fits & 3,41 & 1,089 & 7,442 & 384 & 0,000 & \\
\hline $\begin{array}{l}\text { My job allows me to apply my education and work } \\
\text { experience }\end{array}$ & 3,83 & 0,984 & 16,569 & 384 & 0,000 & \\
\hline I have mastered nearly every aspect of my job. & 3,18 & 1,000 & 3,466 & 384 & 0,001 & \\
\hline I feel that I could easily handle more difficult work. & 3,99 & 0,797 & 24,361 & 384 & 0,000 & \\
\hline I possess more skills than necessary to do my job & 3,61 & 0,921 & 12,948 & 384 & 0,000 & \\
\hline \multicolumn{7}{|l|}{ Top Management Commitment } \\
\hline The managers I work for back me up. & 3,44 & 1,059 & 8,085 & 384 & 0,000 & \multirow{4}{*}{0,886} \\
\hline My superiors take care of my opinions. & 3,58 & 1,002 & 11,391 & 384 & 0,000 & \\
\hline The managers I work for are top notch & 3,29 & 1,139 & 4,920 & 384 & 0,000 & \\
\hline $\begin{array}{l}\text { The organization tries to design my job as } \\
\text { interesting and rewarding as possible }\end{array}$ & 2,68 & 1,185 & $-5,246$ & 384 & 0,000 & \\
\hline
\end{tabular}




\begin{tabular}{|c|c|c|c|c|c|c|}
\hline Job Satisfaction & & & & & & \\
\hline I am satisfied with my current job. & 3,12 & 1,170 & 2,090 & 384 & 0,037 & \multirow{5}{*}{0,920} \\
\hline I really enjoy when I am at work. & 3,30 & 1,094 & 5,451 & 384 & 0,000 & \\
\hline I consider my job very pleasant. & 3,32 & 1,106 & 5,668 & 384 & 0,000 & \\
\hline Each day of my job seems to go quickly. & 3,72 & 1,089 & 13,012 & 384 & 0,000 & \\
\hline $\begin{array}{l}\text { I feel good about the amount of responsibility in } \\
\text { my job. }\end{array}$ & 3,35 & 1,177 & 5,889 & 384 & 0,000 & \\
\hline
\end{tabular}

Notes: (1) Test value for one sample t-test was 3: Neither agrees nor disagrees

In this study, exploratory factor analysis was hired to group all talent waste statements under meaningful factors. Factor analysis is a statistical method to explain variables under reduced number of factors. In this study, the statements were factor analyzed using varimax rotation and principle components analysis. In Table 4, factor analysis for talent waste variables is given. According to the results, sample is sufficient $(\mathrm{KMO}=0,831)$ and suitable for factor analysis (Barlett's test; $\mathrm{p}<0,05)$. Variables of talent waste are grouped under two factors which are named as person-job fit and overqualification. These factors can explain $66,886 \%$ of total variance. It can be seen that there is a strong relation between gender and person-job fit (Pearson Chi-Square value $=37,439, \mathrm{p}=0,010)$.

Table 4: Factor Analysis for Talent Waste

\begin{tabular}{|c|c|c|c|}
\hline & $\begin{array}{c}\text { Factor } \\
\text { Loadings }\end{array}$ & $\begin{array}{c}\% \text { of } \\
\text { Variance }\end{array}$ & $\begin{array}{c}\text { KMO - } \\
\text { Barlett's } \\
\text { Test } \\
\end{array}$ \\
\hline Factor 1: Person-Job Fit & & & \multirow{10}{*}{0,831} \\
\hline My current job offers me sufficient scope to use my knowledge & 0,880 & \multirow{5}{*}{44,291} & \\
\hline My current job offers me sufficient scope to use my skills. & 0,859 & & \\
\hline My educational background and my current job fits & 0,854 & & \\
\hline My skills and my current job fits & 0,787 & & \\
\hline My job allows me to apply my education and work experience & 0,787 & & \\
\hline Factor 2: Overqualification & & & \\
\hline I feel that I could easily handle more difficult work & 0,867 & \multirow{3}{*}{24,595} & \\
\hline If my job would be more challenging, I would perform better. & 0,795 & & \\
\hline I possess more skills than necessary to do my job & 0,700 & & \\
\hline
\end{tabular}

A multiple regression model was applied to investigate whether the association between top management commitment and internal customer job satisfaction depends on the person-job fit and overqualification. The results of the regression equations required to test the mediation model are shown in Table 5 and Table 6 respectively. Baron and Kenny (1986) method was used to test the mediation model. Baron and Kenny (1986) proposed a four-stage approach to present mediation effect in regression analysis. This method is based on conducting several regression analysis and significance of each coefficient. Briefly, if the relationship between independent and dependent variable is no longer significant when intervening variable is controlled, it refers to full mediation; otherwise, it refers to partial mediation.

To start with analyzing the effect of person-job fit; in the first step, results show that there is a positive and significant interaction between top management commitment and internal customer satisfaction $(\beta=0,723, p<0,01)$, in the second step, positive and significant interaction between top management commitment and person-job fit is 
performed $(\beta=0,597, p<0,01)$. Moreover, top management commitment and person-job fit are used as independent variables together and tested the interaction with internal customer satisfaction. Although there is a decline in beta value $(\beta=409, p<0.01)$, there is still a significant relation. Therefore, person-job fit has a partial mediation effect on the association between top management commitment and internal customer satisfaction.

Table 5: Results of Regression Equations Testing Mediation for Person-Job Fit

\begin{tabular}{|l|c|c|c|c|}
\hline & $\mathbf{R}^{2}$ & $\boldsymbol{\beta}$ & $\mathbf{B}$ & $\mathbf{S E}$ \\
\hline 1. Top Man. Com. $\rightarrow$ Internal Cust. Sat. & 0,523 & 0,732 & 1,120 & 0,055 \\
\hline 2. Top Man. Com. $\rightarrow$ Person-Job Fit & 0,357 & 0,597 & 0,723 & 0,050 \\
\hline & & 0,409 & 0,634 & 0,054 \\
\cline { 4 - 6 } 3. Top Man. Com. \& Person-Job Fit $\rightarrow$ In. Cust. Sat. & 0,701 & 0,526 & 0,673 & 0,045 \\
\hline
\end{tabular}

In order to investigate the mediation effect of overqualification on top management commitment and internal customer job satisfaction interaction, same steps of Baron and Kenny (1986) method were applied and the results are shown in Table 6. Overqualification also has a partial mediation effect on top management commitment and internal customer satisfaction since the beta value decreased from $\beta=0,732$ to $\beta=$ $0,688(\mathrm{p}<0.01)$, however, it is still significant.

Table 6: Results of Regression Equations Testing Mediation for Overqualification

\begin{tabular}{|l|c|c|c|c|}
\hline & $\mathbf{R}^{2}$ & $\boldsymbol{\beta}$ & $\mathbf{B}$ & $\mathbf{S E}$ \\
\hline 1. Top Man. Com. $\rightarrow$ Internal Cust. Sat. & 0,523 & 0,732 & 1,120 & 0,055 \\
\hline 2. Top Man. Com. $\rightarrow$ Overqualification & 0,041 & 0,201 & 0,118 & 0,029 \\
\hline & & 0,688 & 1,066 & 0,054 \\
\cline { 5 - 6 } 3. Top Man. Com. \& Overqualification $\rightarrow$ In. Cust. Sat. & 0,553 & 0,176 & 0,465 & 0,092 \\
\hline
\end{tabular}

As a result of the multiple regression analysis, research model has become as in Figure 2. Person-job fit and overqualification partially mediate the relationship between commitment of top management and internal customer job satisfaction. In other words, relationship between commitment of top management and internal customer satisfaction is still significant; however, partial mediation of person-job fit and overqualification are confirmed since beta values have declined. 


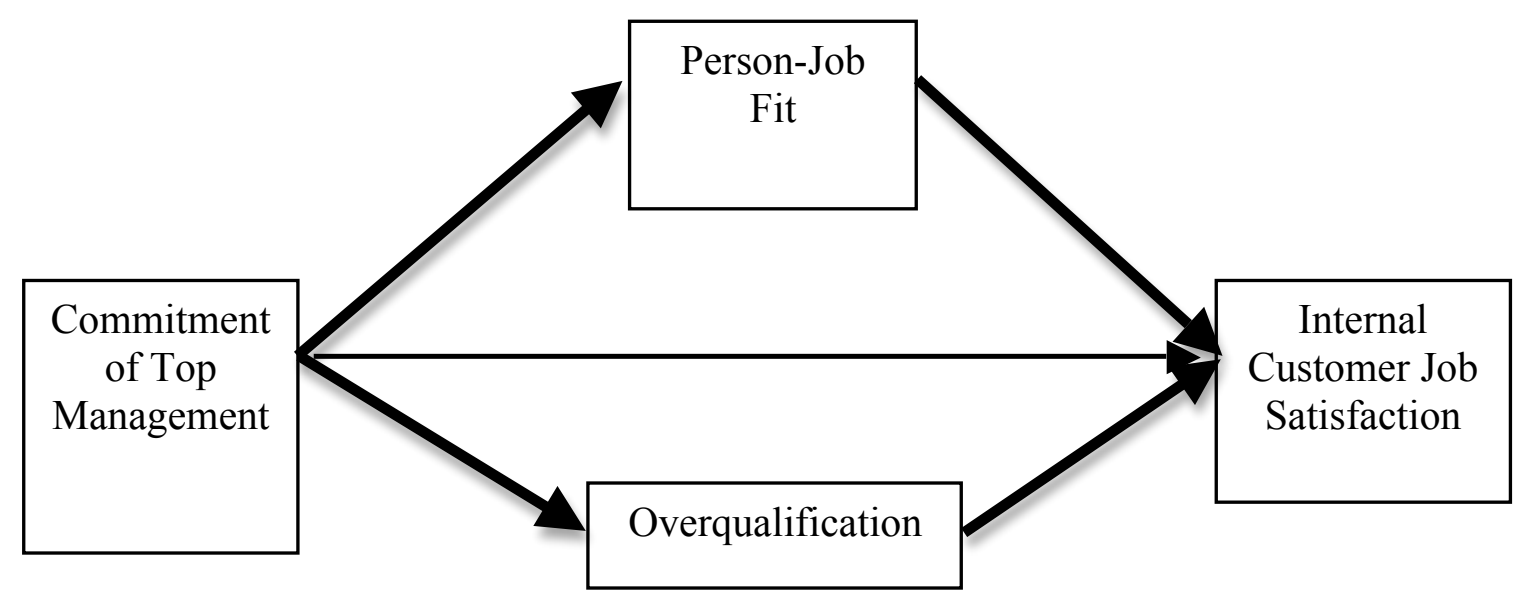

Figure 2. Research Model

With respect to the research model, developed hypothesis was supported. There is a positive relationship between level of top management commitment and internal customer satisfaction and opposite relationship between top management commitment and internal customer satisfaction. Moreover, top management commitment affects the level of talent waste. Research model of the study proved that talent waste partially mediates the relationship between top management commitment and internal customer satisfaction.

\section{Discussions and Conclusions}

In this study, relationship between talent waste and internal customer satisfaction was investigated. Within this context, a survey is conducted with white-collar internal customers to understand their perception of talent waste related to their jobs. Internal customers are one of the most valuable sources of the organizations. Therefore, their level of satisfaction directly affects the organizational performance. When this situation is analyzed from the lean management perspective, wasting talent is a non-value added activity and should be eliminated from the organization to become leaner.

In this study, participants believe that their job allows them to apply their education and work experience and they think they can easily handle more difficult work and they pose more skills than necessary to do their job. Furthermore, results reveal that participants have doubts about their organization's support to design the job interesting and more rewarding. In general, level of internal customer satisfaction was found at moderate level. Person-job fit and overqualification partially mediate the relationship between commitment of top management and internal customer job satisfaction. This paper is expected to contribute by combining well known concepts, such as overqualification, underutilization of skills, job mismatch, with the $8^{\text {th }}$ waste of lean, talent, and investigate its relations to internal customer satisfaction from lean perspective.

For a lean transformation in terms of eliminating talent waste; organization's strategy, top management and human resources management department should be in cooperation. To eliminate and prevent person-job mismatch and overqualification, both in recruitment processes and work design phase, improvements need to be achieved. To 
select the right employee for the right position; educational background checks, testing proficiencies, considering experiences are significant in recruitment processes. Furthermore, to ensure right candidates to apply correct positions, work descriptions and job specifications should be defined in detail before recruitment.

Moreover, in small sized organizations, since the departmentalization is not structured as large-scale organizations, workload of an employee is usually higher. In this kind of organizations, employees must take the responsibility of more than one department. This situation reveals the importance of person-job fit problem in small sized organizations. For a long-term employment, even there is no separate human resources department; management needs to pay attention to ways to eliminate talent waste.

For further studies, tools such as value stream mapping or cause and effect diagrams can be used for detailed analysis of talent waste in organizations. Moreover, investigation of talent waste can be done for a sector or a company by considering special needs and detailed analysis can be conducted.

\section{References}

Ahmed, P. \& Rafiq, M. (2003). "Internal Marketing Issues and Challenges". European Journal of Marketing, Vol. 37 No. 9, 1177-1186.

Alba-Ramirez, A. (1993). "Mismatch in the Spanish Labour Market: Overeducation?" The Journal of Human Resources, Vol. 28, No. 2, 259-278

Allen, J., \& De Weert, E. (2007). "What Do Educational Mismatches Tell Us About Skill Mismatches? A Cross-country Analysis." European Journal of Education, Vol.42, No. 1, 59-73.

Allen, J., \& Van der Velden, R. (2001). "Educational mismatches versus skill mismatches: effects on wages, job satisfaction, and on-the-job search". Oxford Economic Papers, Vol.53 No.3, 434-452.

Al-Yahya, K. O. (2007, August). "The Over-Educated, Under-Utilized Worker: Why Doesn't Human Capital Development Bring Desired Outcomes?". Academy of Management Vol. 2007, No. 1, 1-6.

Badillo Amador, L., López Nicolás, Á., \& Vila, L. E. (2012). "The Consequences on Job Satisfaction of Job-Worker Educational and Skill Mismatches in the Spanish Labour Market: A Panel Analysis". Applied Economics Letters, Vol. 19 No.4, 319-324.

Badillo-Amador, L., \& Vila, L. E. (2013). "Education and Skill Mismatches: Wage and Job Satisfaction Consequences." International Journal of Manpower, Vol. 34, No.5, 416-428.

Bakker, A.B. \& Demerouti, E. (2008), "Towards a Model of Work Engagement", Career Development International, Vol. 13 No.3, 209-223.

Balzer, W. K., Brodke, M. H. \& Kizhakethalackal, E. T., 2015. "Lean Higher Education: Successes, Challenges, and Realizing Potential.” International Journal of Quality \& Reliability, Vol. 32, No.9, 924-933.

Baron, R. M., \& Kenny, D. A. (1986). "The Moderator-Mediator Variable Distinction in Social Psychological Research: Conceptual, Strategic, and Statistical 
Considerations". Journal of Personality and Social Psychology, Vol. 51, No.6, 1173.

Berry, L. L. (1981). “The Employee as Customer”. Journal of Retail Banking, Vol.3, No.1, 33-40.

Bhatti, W. A., Waris, S., \& Zaheer, A. (2011). "The Effect of Commitment and Motivation on Human Talent and its Contribution to Organizational Performance". Management \& Marketing, Vol.6, No.3, 471-482

Brenson, R. \& Kulkarni, N. S., (2011). "Understanding Operational Waste from a Lean Biopharmaceutical Perspective". Pharmaceutical Engineering, Vol.31, No.6, 1-7.

Christer Karlsson Pär Åhlström, (1996),"Assessing Changes towards Lean Production", International Journal of Operations \& Production Management, Vol. 16, No 2, 24 $-41$

Christiansen, N., Sliter, M., \& Frost, C. T. (2014). "What Employees Dislike about Their Jobs: Relationship Between Personality-Based Fit and Work Satisfaction." Personality and Individual Differences, Vol.71, 25-29.

Christopher M. Fleming \& Parvinder Kler (2008) "I'm Too Clever For This Job: A Bivariate Probit Analysis on Overeducation and Job Satisfaction in Australia", Applied Economics, Vol.40, No.9, 1123-1138

Davis, M.A. (2009), "Understanding the Relationship between Mood and Creativity: A Meta-Analysis", Organizational Behavior and Human Decision Processes, Vol.108, No.1, 25-38.

Di Paolo, A., \& Mañé, F. (2014). “Are We Wasting Our Talent? Overqualification and Overskilling among PhD Graduates." (June 17, 2014). XREAP Document de Treball.

Dombrowski, U. \& Mielkea, T., 2013. Lean Leadership Fundamental Principles and Their Application. Setubal, Procedia CIRP .

Elegbe, J. A. (2016). Talent Management in The Developing World: Adopting A Global Perspective. Routledge.

Felstead, A., \& Green, F. (2013). Underutilization, Overqualification and Skills Mismatch: Patterns And Trends. Joint Skills Comitee

Fine, S., \& Nevo, B. (2008). "Too Smart for Their Own Good? A Study of Perceived Cognitive Overqualification in The Workforce." The International Journal of Human Resource Management, Vol. 19, No. 2, 346-355

Fleming, C. M., \& Kler, P. (2014). "Female Overeducation, Job Satisfaction and the Impact of Children at Home in Australia." Economic Analysis and Policy, Vol. 44, No.2, 143-155.

Harmon, J., Scotti, D. J., Behson, S., \& Farias, G. (2003). "Effects of High-Involvement Work Systems on Employee Satisfaction and Service Costs in Veterans Healthcare." Journal of Healthcare Management, Vol. 48, No.6, 393.

Hicks, B. J. (2007). "Lean Information Management: Understanding and Eliminating Waste.” International Journal of Information Management, Vol. 27, No.4, 233249.

Hines, P. \& Rich, N., (1997). “The Seven Value Stream Mapping Tools.” International Journal of Operations \& Production Management, Vol. 17, No.1, 46-64. 
Hines, P., \& Taylor, D. (2000). Going Lean. Cardiff, UK: Lean Enterprise Research Centre Cardiff Business School, 3-43.

Johnson, G. J., \& Johnson, W. R. (2000). "Perceived Overqualification and Dimensions of Job Satisfaction: A Longitudinal Analysis." The Journal of Psychology, Vol. 134, No.5, 537-555.

Karlsson, C. \& Åhlström, P., "Change Processes Towards Lean Production The Role of the Remuneration System", International Journal of Operations \& Production Management, Vol. 15, No.11, 1995, 80-99

Kavanagh, S. \& Krings, D., 2011. "The 8 Sources of Waste and How To Eliminate Them Improving Performance with Lean Management Techniques", Government Finance Review.Vol. 2011, 19-24

Martin, S. \& Arokiam, I., (2007). "An Investigation into the Application of Lean Techniques within the Education Sector". Coventry, Coventry iPED Conference 2007: Researching Academic Futures.

Maskell, B. H. \& Kennedy, F. A., (2007). "Why Do We Need Lean Accounting and How Does It Work?’. Journal of Corporate Accounting \\& Finance, Vol.18, No.3, 59-73.

Matzler, K., Fuchs, M., \& Schubert, A. (2004). "Employee Satisfaction: Does Kano's Model Apply?". Total Quality Management and Business Excellence, Vol. 15, No.9-10, 1179-1198.

Mavromaras, K., Sloane, P., \& Wei, Z. (2012). "The Role of Education Pathways in the Relationship between Job Mismatch, Wages and Job Satisfaction: A Panel Estimation Approach”. Education Economics, Vol.20, No.3, 303-321.

Ohno, T. (1978), Toyota Production System, Diamond, Tokyo

Orpen, C. (1979). "The Effects of Job Enrichment on Employee Satisfaction, Motivation, Involvement, and Performance: A Field Experiment" Human Relations, Vol.32, No.3, 189-217.

Parvin, M. M., \& Kabir, M. N. (2011). "Factors Affecting Employee Job Satisfaction of Pharmaceutical Sector." Australian Journal of Business and Management Research, Vol.1, No.9, 113.

Shah, R., \& Ward, P. T. (2007). "Defining and Developing Measures of Lean Production." Journal of Operations Management, Vol.25, No.4, 785-805.

Spector, P. E. (1997). "Job Satisfaction: Application, Assessment, Causes, and Consequences" Vol. 3, Sage publications.

Stanton, P. et al., (2014). "Implementing Lean Management/Six Sigma in Hospitals: Beyond Empowerment or Work Intensification?" The International Journal of Human Resource Management, Vol.25, No.21, 2926-2940.

Vieira, J. A. C. (2005). "Skill Mismatches and Job Satisfaction." Economics letters, Vol.89, No.1, 39-47.

Viswesvaran, C., Deshpande, S. P., \& Joseph, J. (1998). "Job Satisfaction As a Function of Top Management Support for Ethical Behavior: A Study of Indian Managers.” Journal of Business Ethics, 17(4), 365-371.

Vlachos, I. \& Bogdanovic, A., 2013. "Lean Thinking in The European Hotel Industry." Tourism Management, Vol. 36, 354-363. 
Weymer, A. S. Q., de Oliveira Maciel, C., \& Castor, B. V. J. (2014). “The Influence of the Overqualification and Learning on Individuals' Job Satisfaction". Revista Brasileira de Gestão de Negócios, Vol.16, No.50, 96.

Womack, J. P. \& Jones, D. T., (1996). Lean Thinking: Banish Waste and Create Wealth in Your Organisation. 397 ed. New York: Simon and Shuster. 